\title{
EFFECT OF PRODUCT QUALITY, BRAND IMAGE, AND BRAND TRUST ON PURCHASE INTENTION OF SK-II SKINCARE PRODUCTS BRAND IN JAKARTA
}

\author{
Nelly Then \\ Program Studi Magister Manajemen Universitas Tarumanagara \\ nelly.ymi17@gmail.com \\ Suwinto Johan \\ Program Studi Magister Manajemen Universitas Tarumanagara
}

Masuk : 03-12-2020, revisi : 16-12-2020, diterima untuk diterbitkan : 17-12-2020

\begin{abstract}
The purpose of this research is to analyze the effect of product quality, brand image, brand trust on purchase intention of SK-II skincare products in Jakarta. The independent variable in this research is product quality, brand image, brand trust, and the dependent variable in this research is purchase intention. The sampling technique used in this research is nonprobability sampling by purposive sampling using a quantitative approach. The data collection method was distributed questionnaires to consumers/users of SK-II skincare products in Jakarta with a target of 135 respondents, but only 121 respondents collected, valid data only 100 respondents. The research data was analyzed using the SmartPLS application. Based on the results of the research, it showed that brand image and brand trust have a positive and significant effect on purchase intention, while product quality has no significant effect on purchase intention. To increase customer purchase intention, companies should pay attention to brand trust because brand trust is the vriable that most influences purchase intention.
\end{abstract}

Keywords: Product Quality, Brand Image, Brand Trust, Purchase Intention

\begin{abstract}
Tujuan dari penelitian ini adalah untuk menganalisa pengaruh kualitas produk, citra merek, kepercayaan merek terhadap niat membeli produk skincare merek SK-II di Jakarta. Variabel independent pada penelitian ini adalah kualitas produk, citra merek, kepercayaan merek, dan variabel dependen pada penelitian ini adalah niat membeli. Teknik pengambilan sampel yang digunakan pada penelitian ini adalah nonprobability sampling dengan cara purposive sampling dengan menggunakan pendekatan kuantitatif. Metode pengumpulan data dengan menyebarkan kuesioner kepada konsumen / pengguna produk skincare merek SK-II di Jakarta dengan target 135 respomden, namun yang terkumpul hanya 121 responden, data yang valid hanya 100 responden. Data penelitian dianalisis dengan menggunakan aplikasi SmartPLS. Berdasarkan hasil penelitian yang dilakukan, menunjukkan bahwa citra merek dan kepercayaan merek berpengaruh positif dan signifikan terhadap niat membeli, sedangkan kualitas produk tidak berpengaruh signifikan terhadap niat membeli. Untuk meningkatkan niat beli pelanggan, perusahaan harus memberikan perhatian besar pada kepercayaan merek karena kepercayaan merek merupakan variabel yang paling berpengaruh terhadap niat membeli.
\end{abstract}

Kata kunci: Kualitas Produk, Citra Merek, Kepercayaan Merek, Niat Membeli

\section{INTRODUCTION}

In this era of globalization, the demands and needs of consumers are certainly increasing varied because they have changed from time to time, which in turn, the market is flooded with various products and services, from brands that have a long-time existing brand to new brands just appeared. The company is also competing fiercely to gain an increasingly critical market share, increasing economic conditions and social levels, which means that the standard of living and needs also increases and strives to be the most superior around them. One of the industries that are growing rapidly nowadays and many have sprung up is the cosmetics / skincare 
industry. Minister of Industry Hartarto, quoted from Retnoajeng, (March 22, 2020), said, from BPS data, the cosmetics market segment is very promising, where the cosmetic, skincare and personal care product segments are expected to grow at 9 percent in 2019, and in 2018 it reached around IDR 50 trillion.

The increase in the cosmetics market in Indonesia is not only caused by cosmetics from local brands, but there are still many cosmetic markets in Indonesia that come from abroad. Indonesian consumers prefer to buy foreign cosmetic products rather than local products. Currently, cosmetic products have become a primary need for women who are the main target of the cosmetics industry. According to Kotler and Keller (2009) product quality is the totality of features and characteristics of a product or service that depends on its ability to satisfy stated or implied needs. According to Tjiptono (2011) brand image is a description of the association and consumer confidence in certain brands. According to Ferrinnadewi (2008) brand trust is a brand's ability to be trusted, which comes from consumer confidence that the product is able to fulfill the promised value and brand intention which is based on consumer belief that the brand is able to prioritize consumer interests. According to Belch (2004) purchase intention is the tendency to buy a brand, generally based on the suitability of the purchase motive with the attributes or characteristics of the brand that can be considered. The results of this study are expected that companies must pay attention to the factors of product quality, brand image and brand trust in the company's operational activities. This is because these three factors have the potential to create customer decisions that will increase purchase intention.

\section{LITERATURE REVIEW AND HYPOTHESES Product Quality}

Product quality according to Kotler and Armstrong (2008) is the product's ability to carry out various functions including durability, reliability, accuracy, and ease of use. According to Schiffman and Kanuk (2007), product quality is the ability of a company to give identity or characteristics to each product so that consumers can recognize the product. According to research by Basha et al. (2015) Product Quality has a significant influence and is the main motive for purchase intention.

\section{Brand Image}

According to Kotler (2008), measuring brand image can be done based on 3 indicators as follows: 1. Strength is the advantages possessed by a physical brand that are not found in other brands. 2. Uniqueness is the ability to differentiate a brand among other brands. 3. Favorable to choose what is likable and unique in relation to the brand, marketers must carefully analyze the consumer and the competition to decide the best position for the brand. According to Erdil (2015) research, brand image influences consumer behavior in purchase intention. Wang et al. (2014) stated that brand image has a positive and significant effect directly on purchase intention.

\section{Brand Trust}

According to Lau and Lee quoted from Khoza and Harjati, 2012, three factors influence brand trust. These three factors are the three entities involved in the relationship between brands and consumers. The relationship between these three factors and brand trust can be described as follows: Brand characteristics have a very important role in determining the analysis and evaluation of consumers to trust a brand. The company characteristics behind a brand can also affect the level of consumer confidence in the brand. The consumer-brand characteristics are two groups that influence each other. These characteristics include the similarity between the emotional concept of the consumer and the brand personality, liking for the brand, and the experience of the brand. According to research by Cuong (2020) states that brand trust has a positive influence on the purchase intention of a product. Ali et al. (2017) state that brand image has a strong influence on purchase intention. 


\section{Purchase Intention}

Purchase intention, according to Kotler (2009), a person's activity or behavior that arises through the response so that it shows the customer's desire to purchase on an object. According to Kotler (2008) there are four stages of producers in determining purchase interest or determining consumer motivation in making purchases of products or services offered, including: Attention is the initial stage in assessing a product or service according to the needs of prospective customers, besides those prospective customers also learn about the products or services offered. Interest potential customers begin to be interested in buying the products or services offered, after getting more detailed information about the products or services offered. Desire where potential customers begin to thinking and discussing the products or services offered because the desire and desire to buy begins to emerge. Action where the prospect has high stability to buy or use the product or service offered.

Based on the results of the above research, the following hypothesis can be formulated:

H1: Product quality has a significant influence on the purchase intention of SK-II skincare products in Jakarta.

$\mathrm{H} 2$ : Brand image has a significant influence on the purchase intention of SK-II skincare products in Jakarta.

H3: Brand trust has a significant influence on the purchase intention of SK-II skincare products in Jakarta.

\section{Figure 1}

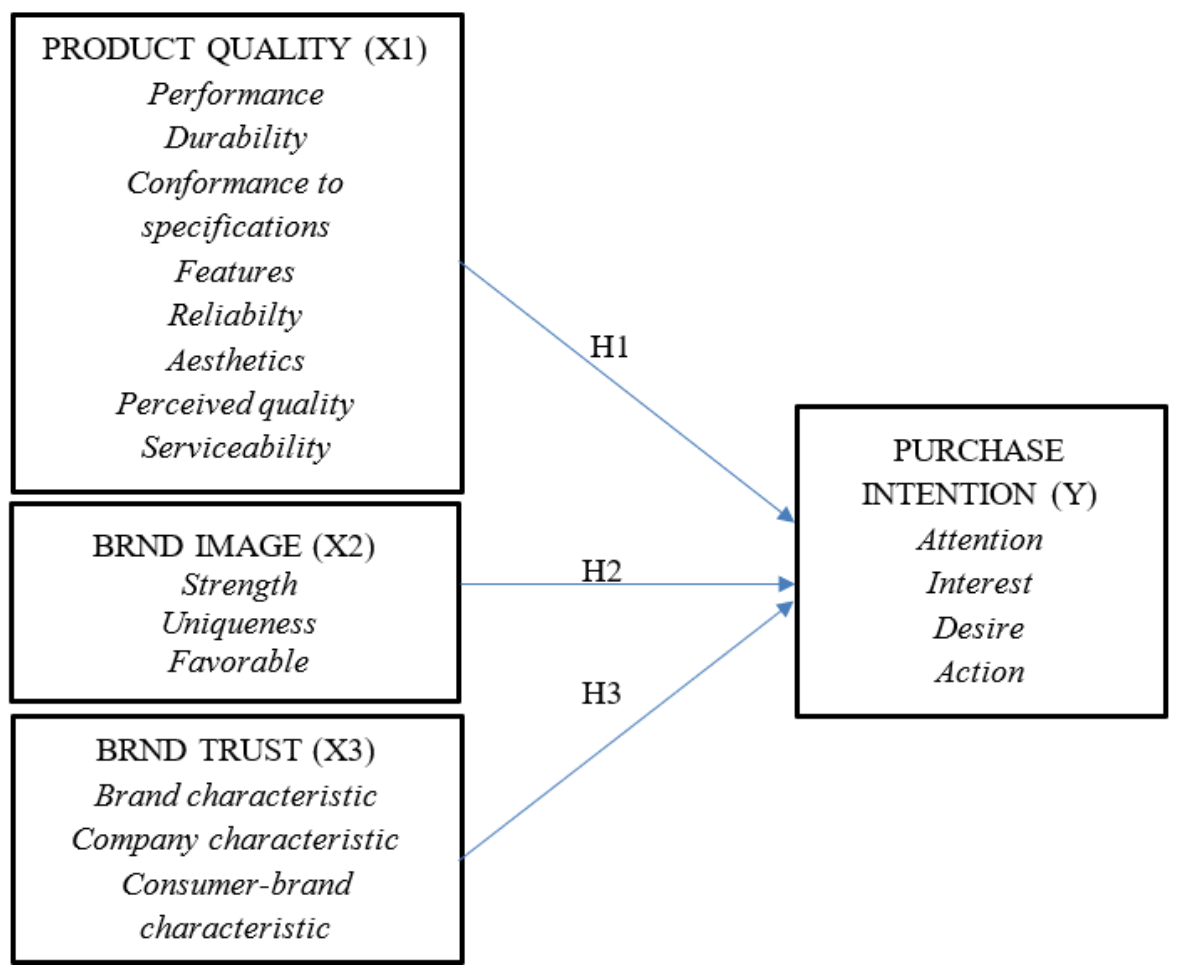

\section{RESEARCH METHODOLOGY \\ Population and Sample}

This type of research used in this research is quantitative research. According to (Kaisram 2008) quantitative is a research method that uses the process of data in the form of numbers as a tool to analyze and conduct research, especially regarding what has been studied. To determine the measurement of respondents, answer in this study using a research instrument in the form of a questionnaire, the authors used the Likert scale method 1-5 points. The population in this study were consumers/users of SK-II skincare products in Jakarta. The sample selection design was a non-probability sample. The sampling technique used was purposive sampling where the criteria for selecting the sample of consumers were those who used and had 
purchased skincare products from the SK-II brand in Jakarta. The target sample is 135, but the number of respondents in the distribution of this questionnaire is only 121 , valid data is only 100 respondents because the other 21 respondents are not consumers who use / have purchased skincare products from the SK-II brand in Jakarta. From the results of the study 100 respondents were female, age range 25-30 years 42\%, 30-35 years 40\% and domiciled in North Jakarta $44 \%$, with the latest education status are Bachelor $60 \%$. Monthly income of IDR $12,000,000$ - IDR $16,000,000$ as much as $32 \%$, > IDR 16,000,000 as much as $40 \%$, monthly expenses in the range of IDR 6,000,000 - IDR 8,000,000 as much as 59\%, and the frequency of often buying SK-II brand skincare products in Jakarta by $52 \%$.

\section{RESULTS AND DISCUSSION}

\section{Tabel 1}

Significant Test Results

\begin{tabular}{|c|c|c|c|c|c|}
\hline & $\begin{array}{c}\text { Original } \\
\text { Sample (O) }\end{array}$ & $\begin{array}{c}\text { Sample } \\
\text { Mean (M) }\end{array}$ & $\begin{array}{c}\text { Standard } \\
\text { Deviation } \\
\text { (STDEV) }\end{array}$ & $\begin{array}{c}\text { T Statistics } \\
(\mid \mathrm{O} / \text { STDEV|) }\end{array}$ & $\begin{array}{c}\text { P } \\
\text { Values }\end{array}$ \\
\hline $\begin{array}{c}\text { X1 (Product Quality) } \rightarrow \text { Y (Purchase } \\
\text { Intention) }\end{array}$ & 0.084 & 0.120 & 0.086 & 0.979 & 0.328 \\
\hline $\begin{array}{c}\text { X2 (Brand Image) } \rightarrow \text { Y (Purchase } \\
\text { Intention) }\end{array}$ & 0.178 & 0.206 & 0.085 & 2.085 & 0.038 \\
\hline $\begin{array}{c}\text { X3 (Brand Trust) } \rightarrow \text { Y (Purchase } \\
\text { Intention) }\end{array}$ & 0.375 & 0.377 & 0.101 & 3.720 & 0.000 \\
\hline
\end{tabular}

Source: Research Results

Product quality does not have a significant effect on the purchase intention of SK-II skincare products in Jakarta

The product quality variable on the purchase intention of SK-II skincare products in Jakarta has no significant effect because the T statistic on product quality value $<1.96$, which is 0.979 . The $\mathrm{P}$ value on product quality on the purchase intention of SK-II skincare products in Jakarta is not significant/rejected because the value $>0.05$, which is 0.328 . The results of the hypothesis on the effect of product quality on purchase intention are not contradicting the results of research conducted by Basha et al., (2015) which are the most commonly stated influence for purchase intention. However, the result research differed from the results of research conducted by Hulu et al (2018) which states that product quality has no effect on purchase intention. Good product quality does not increase consumer confidence, this means that SK-II should improve the product and variants. Product quality is an indicator of how much value or benefit the product to customers, if the quality elements in a product are felt in accordance what consumers want and consumer needs, that will increase purchase intention.

Brand image has a significant influence on the purchase intention of SK-II skincare products in Jakarta

The brand image variable on the purchase intention of SK-II skincare products in Jakarta significant effect because the $\mathrm{T}$ statistic on product quality value $>1.96$, which is 2,049 . The $\mathrm{P}$ value on brand image on the purchase intention of SK-II skincare products in Jakarta is significant/contradict because the value $<0.05$, which is 0.038 . The results of the hypothesis of the effect of brand image on purchase intention are significant and in line with the research conducted by Erdil (2015) and Wang et al. (2014). A good brand image has an influence on consumer confidence in a product and in the end will lead to purchase intentions. In other words, companies that have a good brand image can influence purchase intentions.

Brand trust has a significant influence on the purchase intention of SK-II skincare products in Jakarta

The brand trust variable on the purchase intention of SK-II skincare products in Jakarta significant effect because the $\mathrm{T}$ statistic on product quality value $>1.96$, which is 3,720 . The $\mathrm{P}$ value on brand trust on the purchase intention of SK-II skincare products in Jakarta is 
significant/contradict because the value $<0.05$, which is 0.000 . The results of the hypothesis of the effect of brand image on purchase intention are significant and in line with the research conducted by Cuong (2020) and Ali et al. (2017). Purchase intention will increase due to the brand's ability to be trusted, which is rooted in consumer confidence that the brand is able to fulfill the promised value based on consumer confidence that the brand is able to prioritize interests.

\section{CONCLUSIONS AND SUGGESTIONS}

Based on the results of the research conducted, there is no significant effect of product quality on the purchase intention SK-II skincare products in Jakarta because consumers see product quality as important but not the main factor of purchase intention. Consumers already know the product quality of the product, but consumers think more about trends and social status in purchase intention of SK-II skincare products. There is a significant influence of brand image on the purchase intention of SK-II skincare products in Jakarta because consumers have a good brand perception and are embedded in consumers memories, both from the brand name, logo and colors used by SK-II which are very easy to remember. Consumers have a strong belief and preference for SK-II skincare products. There is a significant influence of brand trust on the purchase intention of SK-II skincare products in Jakarta because consumers believe that SK-II able to provide positive and good results as promised. Consumers believe that the SK-II brand is a safe brand to use and reduces perceptions of skin risks, and that the SK-II brand is able to fulfill self-concepts, needs and values. It can be concluded that the objectives of this study regarding product quality, brand image, and brand trust on purchase intention have been answered and achieved.

The results of this study can be used as material for consideration and evaluation regarding product quality, brand image, brand trust on purchase intention of SK-II skincare products. From the findings in this study, it was found that brand trust in SK-II skincare products has a high value compared to brand image in SK-II skincare products. With high brand trust, consumers no longer see product quality as one of the most important reasons for their intention to buy skincare products from the SK-II brand.

This study has several limitations in data processing, because the data processed in this study specifically only examines consumers / users of SK-II skincare products in Jakarta. This study only uses the variables of product quality, brand image, brand trust and purchase intention.

For academics, further researchers should increase the number of respondents, add research objects and develop variables in subsequent research so that the results obtained are more accurate and strengthen research results and expand the reach of the population and sample. For the Company, suggestions for companies to increase brand image and brand trust, companies or marketers of SK-II brand products in Jakarta need to strengthen their brand image and maintain company reputation so that consumers can remember the SK-II brand and can also increase consumer intention to buy.

\section{REFERENCES}

Ali, A., Guo, X., \& Sherwani, M. (2017). Antecedents of consumer's Halal brand purchase intention: an integrated approach. Emerald Insight Journal.

Basha, M. B., Mason, C., Shamsudin, M. F., Hussain, H. I., \& Salem, M. A. (2015). Consumers Attitude Towards Organic Food. Elsevier Journal.

Belch, G. E, \& Belch, M. A. (2004). Advertising and Promotion, 6th Edition.

Cuong, D. T. (2020). The role of brand trust as a mediator in the relationship between brand satisfaction and purchase intention. International Journal of Psychosocial Rehabilitation, 24. 
Erdil, T. S. (2015). Effects of customer brand perceptions on store image and purchase intention: An application in apparel clothing. Elsevier Journal.

Ferrinadewi, E. (2008). Merek dan Psikologi Konsumen: Implikasi pada Strategi Pemasaran. Yogyakarta: Graha Ilmu.

Ghozali, I. H., \& Latan, H. (2015). Partial Least Squares: Konsep, teknik, dan aplikasi menggunakan program smart PLS 3.0 (2nd ed.). Semarang: Universitas Diponegoro Semarang.

Hulu, P., Ruswanti, E., \& Hapsari, N. P. (2018). Influence of Product Quality, Promotion, Brand Image, Consumer Trust towards Purchase Intention: Study Case on Pocari Sweat Isotonic Drink. IOSR Journal of Business and Management.

Kasiram, M. (2008). Metodologi Penelitian. Malang: UIN-Malang Pers.

Khoza., H. (2012). Analisis Brand Trust Dan Brand Royalty Konsumen Garuda Indonesia. Jurnal.

Konsumen Indonesia Lebih Suka Merek Kosmetik Global. (2016). Databoks, from Databoks website: https://databoks.katadata.co.id/datapublish/2016/11/17/konsumen-indonesialebih-suka-merek-kosmetik-global. Retrived on August 2020.

Kotler, P., \& Amstrong, G. (2008). Prinsip-prinsip Pemasaran Jilid 1. (Terjemahan Bob Sabran). Edisi Keduabelas. Jakarta: Erlangga. (Edisi asli diterbitkan tahun 2008 oleh Pearson Education Inc. Pearson Prentice Hall)

Kotler, P., \& Keller, K. L. (2009). Manajemen Pemasaran Buku 1. Jakarta : Erlangga.

Retonoajeng. (2020). Kosmetik Lokal yang Ditinggalkan Akibat Masuknya Kosmetik Global ke Indonesia.

Schiffman, \& Kanuk. (2007). Perilaku Konsumen. Edisi Kedua. Jakarta: PT. Indeks Gramedia. Tjiptono, F. (2011). Manajemen dan Strategi Merek. Yogyakarta: Penerbit Andi.

Wang, Y. H., \& Tsai, C. F. (2014). The relationship between brand image and purchase intention: Evidence from award winning mutual funds. The International Journal of Business and Finance Research. 